\section{Variation in Leafhopper Species Abundance and Diversity among Elm Seedlings and Cultivars}

\author{
Jo-Ann Bentz ${ }^{1}$ \\ U.S. Department of Agriculture, Agricultural Research Service, U.S. National \\ Arboretum, Floral and Nursery Plants Research Unit, 10300 Baltimore Avenue, \\ BARC-West, Building 010A, Room 238, Beltsville, MD 20705-2350
}

\begin{abstract}
Alden M. Townsend ${ }^{2}$
U.S. Department of Agriculture, Agricultural Research Service, U.S. National Arboretum, Floral and Nursery Plants Research Unit, 11601 Old Pond Drive, Glenn Dale, MD 20769
\end{abstract}

Additional index words. species richness, species evenness, species equitability, Simpson's 1-D index, Berger-Parker index, host plant resistance, Ulmus

\begin{abstract}
A survey was conducted in the 2001 growing season to determine the leafhopper species composition, abundance, richness, diversity, and evenness among trees of three elm (Ulmus sp.) cultivars, two U.S. National Arboretum (USNA) seedling selections of $\boldsymbol{U}$. szechuanica Fang, and two USNA seedling selections of $U$. bergmanniana Schneid. in a mixed stand. Yellow sticky traps were used to qualify and quantify the number of aerial leafhoppers from 1 May 2001 until 4 September 2001. A total of 4,523 individuals, belonging to 39 species within seven leafhopper subfamilies, were trapped. The weekly mean number of leafhoppers collected was significantly higher on traps from 'Patriot', followed by 'Frontier' and 'Prospector', than on traps from the USNA seedling selections. Although the weekly mean species richness for 'Prospector' was lower than the other two cultivars, the three cultivars had higher mean species richness than the USNA seedling selections of $U$. szechuanica and $U$. bergmanniana. Diversity among cultivars was higher than among the USNA seedling selections. Ulmus bergmanniana 68983 and $U$. szechuanica 68986 shared the highest percentage of species similarity, while 'Frontier' and $U$. szechuanica 68991 were the most dissimilar. Of the species collected, Agallia quadripunctata, Empoasca fabae and Graphocephala versuta were the most abundant. The other species were mostly rare based on their low abundance. Scaphoideus luteolus, the only confirmed vector of elm yellows in North America, was found among the elm cultivars only. Yet, the Cicadellinae leafhoppers that are vectors of Xylella fastidiosa, the causal agent of bacterial leaf scorch, were found among both the cultivars and USNA seedling selections. Such data could allow for the screening and selection of elms resistant to economically important leafhoppers.
\end{abstract}

Several leafhopper species are commonly found infesting elms (Ulmus spp.) (Beirne, 1956; Hamilton, 1985). Many of these species are not of economic importance and their presence may go unnoticed. Others are important because of the feeding damage that they cause, or because they vector plant pathogens that cause diseases such as elm yellows (formerly called phloem necrosis) (Gleason, 2001), and bacterial leaf scorch (Bentz and Sherald, 2001). The feeding of most leafhoppers causes white stippling on foliage, or browning, stunting, withering and curling of leaves. These leafhoppers frequently require insecticidal treatments

\footnotetext{
Received for publication 10 Dec. 2004. Accepted for publication $24 \mathrm{Feb} .2005$. We are very grateful to Tom Abell, Amy Barbosa and Iris Mars for their technical assistance, and to Marcial Pastor-Corrales and William Lamp for reviewing an early draft of the manuscript. Mention of a proprietary product does not constitute an endorsement or a recommendation by the USDA for its use.

${ }^{1}$ Research entomologist. To whom reprint requests should be addressed; e-mail bentzj@ba.ars.usda. gov.

${ }^{2}$ Research geneticist.
}

for their control and for curtailing the feeding damage they cause.

Limited information is available about the leafhopper species associated with elms. Gibson (1973) listed 87 leafhopper species that were collected on american elm (U. americana L.) or from trees or herbaceous vegetation in association with elm. Hamilton (1985) noted that the leafhopper fauna of introduced elms in Canada differed from that of native elms. Yet, no work has been done to elucidate the effect of elm species, cultivar, or seedlot (i.e., forest seed origins) on leafhopper species diversity and abundance. Because new elm varieties are being developed and used in the landscape, these potentially could influence leafhopper populations. For example, we previously showed that the potato leafhopper (Empoasca fabae) (Homoptera: Cicadellidae), exhibits ovipositional preferences among elm cultivars that relate, in part, to varietal differences in the foliar element content (Bentz and Townsend, 2001). We collected more leafhopper adults from american elm than from other elms, and found that more eggs were laid and more nymphs became adults on american elm and on 'Patriot'
('Patriot' = 'Urban' $[=U$. pumila L. $\times(U$. hollandica Mill. 'Vegeta' $\times$ U. carpinifolia Gled.)] $\times$ 'Prospector' $[=U$. wilsoniana Schneid. $]$ ) than on 'Prospector', U. wilsoniana, elm.

Species richness and species evenness are the two essential components that define species diversity. Species richness is a count of the total number of species in the area under study, and is expressed as a single number. Species evenness is a measure of the relative abundance of the species in the area under study, i.e., a measure of how similar species are in their abundances. Evenness is expressed as a percentage or a proportion. Thus, an assemblage in which most species are equally abundant is one that has high evenness. Several diversity indices have been developed that take into account both richness and evenness to generate a single statistic (see Magurran, 2003). Diversity indices provide important information aboutrarity and commonness of species, and facilitate the comparison of species between communities or assemblages. Thus, the objectives of this study were to determine leafhopper abundance, diversity, richness, and species composition, and the occurrence of known vector species occurring among trees in a mixed stand of different elm selections. Such data could facilitate the selection of elms with resistance to leafhoppers, and thus, lead to reduced pesticide usage.

\section{Materials and Methods}

Field plot. The experiment was conducted at the U.S. Department of Agriculture (USDA), Agricultural Research Service (ARS) station near Glenn Dale, Md., using a research field plot that is part of the U.S. National Arboretum (USNA) Tree Breeding Program. The field plot consisted of two blocks of trees arranged within rows by elm selection in a completely randomized block design. Blocks were separated by a 9.2 m wide east-west corridor. Each block contained 11 rows $3.7 \mathrm{~m}$ apart with 17 or 18 trees separated by $3.1 \mathrm{~m}$ within the rows. The plot was surrounded by mixed vegetation including such trees as maples and alders, and mowed every other week or as needed. Trees were irrigated only during very hot and dry periods. No fertilizers or pesticides were applied during the course of the study.

Elm selections. Two adjacent ramets (trees which result from vegetative propagation of a single clone) of each of the three USNA elm cultivars - 'Frontier'( U. carpinifolia Gleditsch. $\times U$. parvifolia Jacq.), 'Prospector', and 'Patriot'-were tagged per block using flagging tape (Gempler's, Belleville, Wis.) and used in this study. In addition, two elm seedlings (trees grown from seeds) of Chinese origin of U. bergmanniana Schneid. (USNA 68983 and 68997 from different seedlots), and of $U$. szechuanica Fang (USNA 68986 and 68991 from different seedlots), were tagged per block and included in the study. Thus, 7 elm selections with a total of 12 ramet-trees and 8 seedling-trees were selected for the study. The clonal ramets were transplanted in 1989 and the seedlings were transplanted in 1997. The height of all the trees was estimated as ranging from 6 to $8 \mathrm{~m}$.

Trapping of leafhoppers. Because sticky 


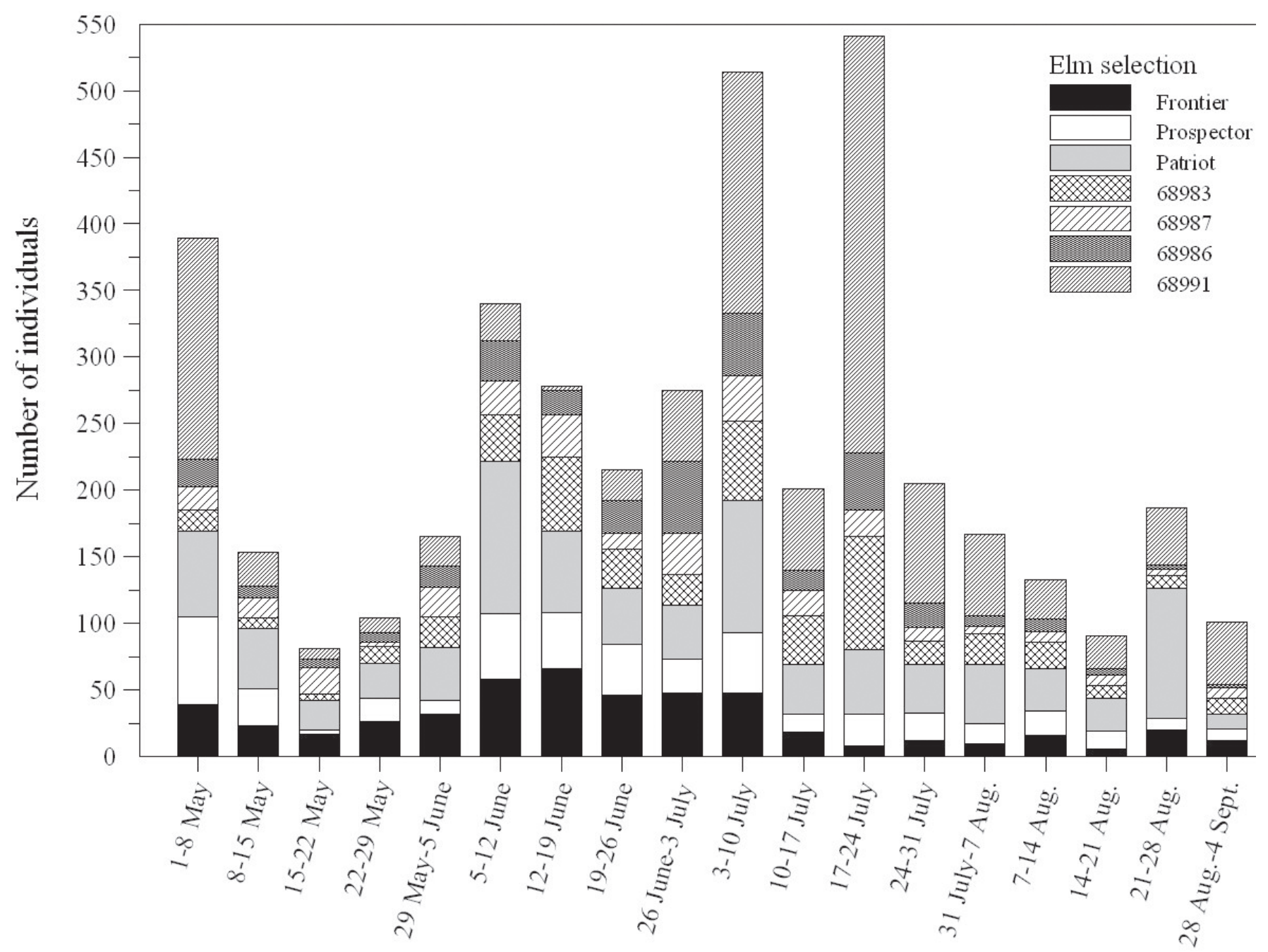

Fig. 1. Number of leafhopper individuals collected among different elm selections during 18 consecutive sampling weeks of the 2001 growing season. Elm selections 68983 and 68987 are Ulmus bergmanniana. Elm selections 68986 and 68991 are U. szechuanica.

traps have been used successfully in monitoring leafhoppers and provide a continuous record of leafhopper abundance and activity (Purcell and Elkinton, 1980), these were used in the present study to monitor aerial leafhopper populations. Yellow sticky traps $\left(97 \mathrm{~cm}^{2}\right)$ (Gempler's) were hung on the west side of tagged trees on a branch in the lower periphery of each tree at about $4 \mathrm{~m}$ above the ground on 1 May 2001. Traps were changed weekly until 28 Aug. 2001. Final traps were taken down on 4 Sept. 2001. Collected traps were examined in the laboratory with a stereomicroscope. Leafhoppers were carefully removed using a dissecting probe, transferred into transparent cups, and counted.

Leafhoppers were identified to species level by one of the authors (J.B.). Several of the species were clearly recognizable externally. For those leafhoppers that were not easily recognized, the male genitalia or the female's seventh sternum were examined and identified using available insect keys. Accurate information on elms is lacking regarding the host range or host utilization of leafhoppers that are not economically important. For a species to be considered in this study it had to be collected from both blocks, minimizing the number of casual visitors (sensu Oman, 1949). Thus, 17 species, mostly single- tons, were excluded from the analyses because they occurred in only one block.

Statistical analyses. The weekly number of species found on traps and the number of individuals of each species collected weekly were determined for each selection per block per tree using the PROC MEANS procedure within the SAS software program (SAS Institute, 1999). These totals were then used for the calculation of weekly values of richness (i.e., the number of species), Simpson's 1-D (i.e., the probability that two individuals randomly selected from a sample will belong to different species), equitability (i.e., the evenness with which individuals are divided among the species present calculated as the Shannon diversity index divided by the logarithm of number of species), and BergerParker (i.e., the number of individuals in the dominant species relative to the total number of individuals) indices using the software program PAST (Hammer et al., 2004).

Data for each dependent variable were $\log _{10}(\mathrm{x}+1)$ transformed before analyses to correct for lack of normality. Because the data were collected over 18 weeks, dependent variables were analyzed using a repeated measures oneway analysis of variance with elm selection tested as a main effect, and using the repeated statement with autoregressive covariance in PROC MIXED within SAS (Littell etal., 1996).

Means and standard errors of the means (SE) were generated using the LSMEAN statement and compared using contrasts at $P=0.05$. Species similarity among elm selections was tested using the Renkonen similarity index with the software program Ecological Methodology (Krebs, 2002). Species evenness was calculated as a percent of the total number of individuals collected during the 2001 growing season.

\section{Results}

In total, 4,523 leafhopper individuals were collected from the traps on trees of the seven different elms during the 2001 growing season. The number of leafhoppers collected differed among sampling weeks (Fig. 1). The fewest leafhoppers were collected during 15 to 22 May, while the most leafhoppers were collected during 17 to 24 July (Fig. 1). The weekly mean number of leafhoppers collected per trap was significantly different among elm selections $(F=30.43$; $\mathrm{df}=$ $6,7 ; P<0.0001$ ) (Table 1$)$. The weekly mean number of leafhoppers was significantly higher on traps from trees of 'Patriot', followed by 'Frontier' and 'Prospector', than on traps from 
Table 1 . Weekly means \pm SE $\left(\log _{10}\right)$ per trap for the number of individuals collected, leafhopper species richness, and diversity indices collected during the 2001 season among seven different elm (Ulmus) selections.

\begin{tabular}{|c|c|c|c|c|c|}
\hline$\overline{\text { Elm selection }}$ & Individuals ${ }^{\mathrm{z}}$ & Richness & Simpson 1-D & Equitability & Berger-Parker \\
\hline Prospector & $0.73 \pm 0.033 b$ & $0.53 \pm 0.017 b$ & $0.15 \pm 0.006 \mathrm{a}$ & $0.21 \pm 0.008 \mathrm{a}$ & $0.19 \pm 0.005 \mathrm{a}$ \\
\hline U. bergmanniana 68983 & $0.53 \pm 0.033 \mathrm{c}$ & $0.31 \pm 0.017 \mathrm{c}$ & $0.09 \pm 0.006 b$ & $0.12 \pm 0.008 b$ & $0.09 \pm 0.005 b$ \\
\hline U. szechuanica 68986 & $0.42 \pm 0.033 \mathrm{~d}$ & $0.29 \pm 0.017 \mathrm{c}$ & $0.08 \pm 0.006 \mathrm{~b}$ & $0.11 \pm 0.008 \mathrm{~b}$ & $0.09 \pm 0.005 b$ \\
\hline U. szechuanica 68991 & $0.57 \pm 0.033 \mathrm{c}$ & $0.32 \pm 0.017 \mathrm{c}$ & $0.08 \pm 0.006 \mathrm{~b}$ & $0.11 \pm 0.008 b$ & $0.09 \pm 0.005 b$ \\
\hline
\end{tabular}

${ }^{\mathrm{z}}$ Means within columns followed by the same letter are not significantly different at $P<0.05$ (contrast).

trees of the four USNA seedling selections. Weekly traps on U. szechuanica 68986 collected significantly fewer leafhoppers than traps on the other USNA seedling selections.

The number of species collected among the elm selections varied over the season (Fig. 2). Species richness was highest during 3 to 10 July, ranging from 21 species collected on traps from 'Frontier' to 10 species collected on traps from U. bergmanniana 68997. The weekly mean species richness was significantly different among elm selections $(F=66.11 ; \mathrm{df}=6,7 ; P$ $<0.0001)$ (Table 1). The weekly mean species richness was not significantly different among USNA seedling selections, but their weekly mean species richness was significantly lower than that of the cultivars. The weekly mean species richness for 'Prospector' was significantly lower than the weekly mean richness for the other cultivars. The weekly mean Simpson's 1 -D index $(F=32.38 ; \mathrm{df}=6,7 ; P<0.0001)$, weekly mean species equitability $(F=43.09$; $\mathrm{df}=6,7 ; P<0.0001)$, and the weekly mean Berger-Parker index $(F=78.64 ; \mathrm{df}=6,7 ; P<$ 0.0001 ) indicated that diversity among cultivars was significantly higher than among the USNA seedling selections, with a more even distribution of individuals among cultivars than among the seedlings (Table 1).

Ulmus bergmanniana 68983 and U. szechuanica 68986 shared the highest percentage of species similarity $(84 \%)$, followed by $U$. bergmanniana 68997 and U. szechuanica 68991 (83\%) (Table 2). 'Frontier' and U. szechuanica 68991 were the most dissimilar (30\%). Species similarity ranged from $70 \%$ to $77 \%$ among the cultivars, from $53 \%$ to $84 \%$ among the seedling selections, and from $30 \%$ to $61 \%$ among the cultivars and seedling selections.

Most species were not consistently collected over sampling weeks (Fig. 3). Of those species for which $>10$ individuals were collected during the season, only Graphocephala versuta and Erythroneura comes were found on traps during each week (Fig. 3). While Alebra albostriella was found only early in the season, Coelidia olitoria was found only after July. In total, 39 different leafhopper species from 7 different

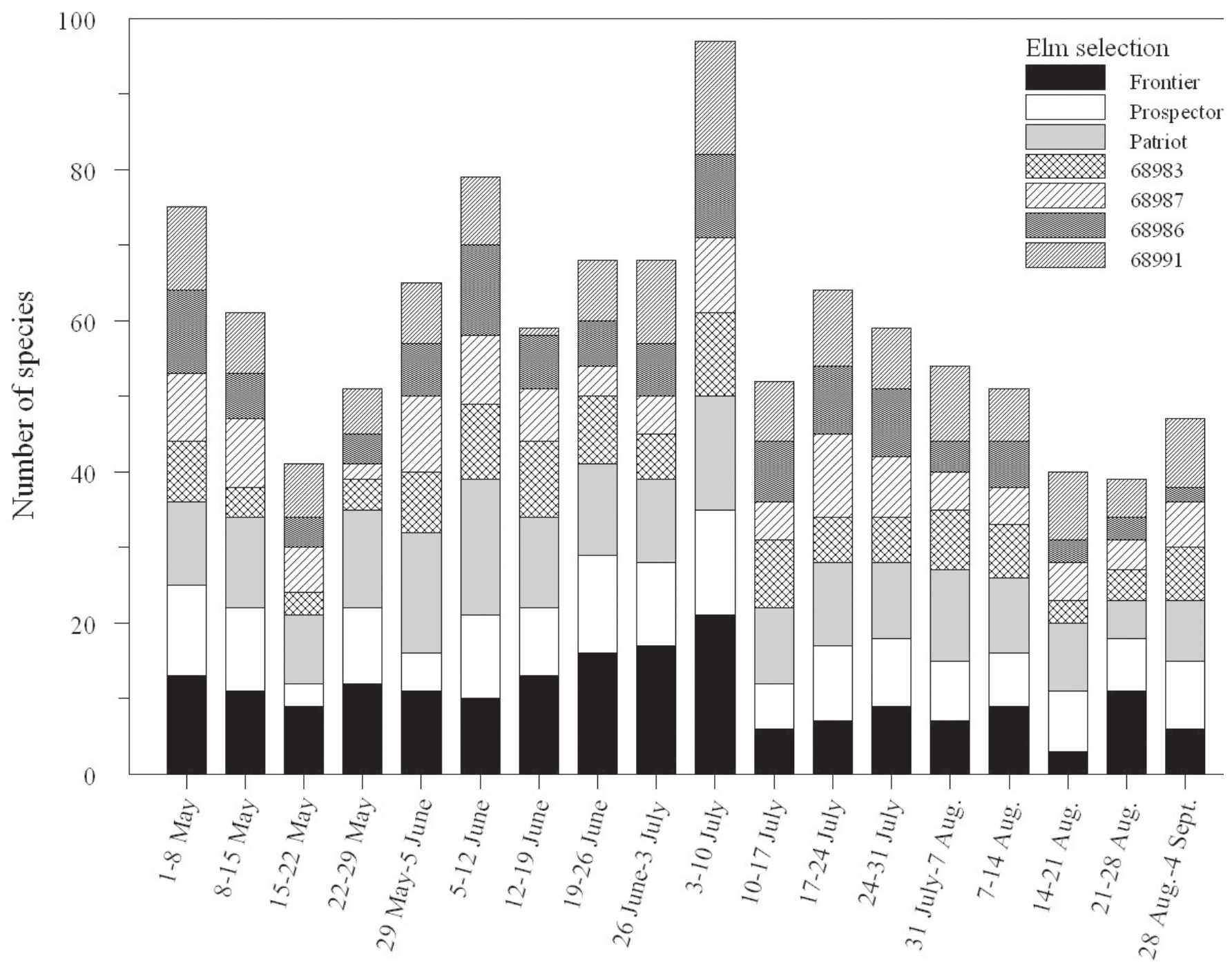

Fig. 2. Number of species collected among different elm selections during 18 consecutive sampling weeks of the 2001 growing season. Elm selections 68983 and 68987 are Ulmus bergmanniana. Elm selections 68986 and 68991 are U. szechuanica. 
Table 2. Percent leafhopper species similarity matrix among elm (Ulmus) selections using the Renkonen index.

\begin{tabular}{lccccccr}
\hline & \multicolumn{7}{c}{ Elm selection } \\
\cline { 2 - 8 } Elm selection & Frontier & Prospector & Patriot & 68983 & 68997 & 68986 & 68991 \\
\hline Frontier & 100 & & & & & & \\
Prospector & 76.58 & 100 & & & & & \\
Patriot & 70.46 & 70.07 & 100 & & & & \\
U. bergmanniana 68983 & 49.15 & 49.16 & 57.43 & 100 & & & \\
U. bergmanniana 68997 & 34.62 & 39.37 & 50.34 & 60.15 & 100 & & \\
U. szechuanica 68986 & 60.00 & 58.32 & 61.21 & 84.02 & 57.09 & 100 & \\
U. szechuanica 68991 & 30.38 & 35.27 & 46.24 & 61.75 & 83.00 & 52.56 & 100 \\
\hline
\end{tabular}

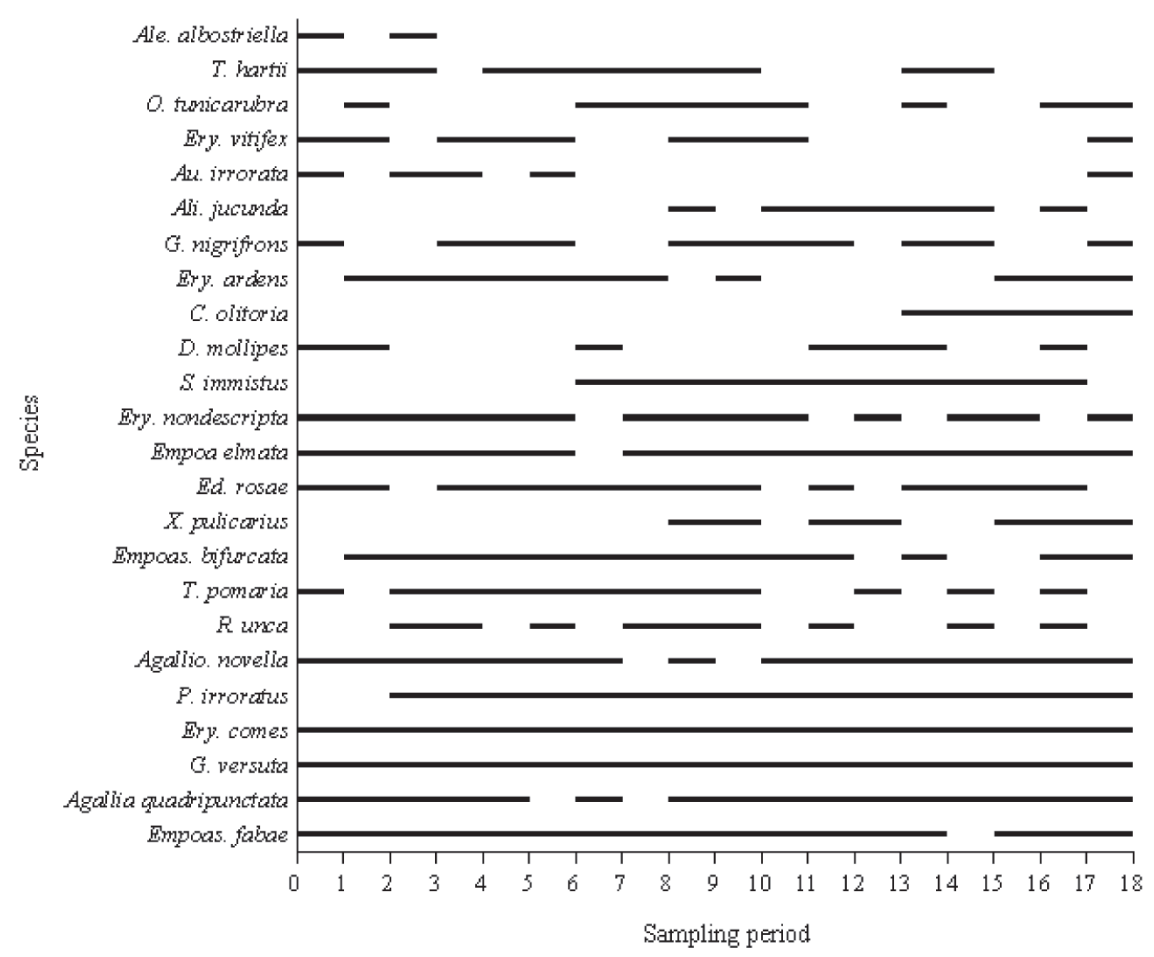

Fig. 3. Species occurrence during the 18 consecutive sampling weeks of the 2001 growing season. Solid bars indicate when species were collected. Species for which $<10$ individuals were collected for the season were not included. Sampling periods: $1=1$ to 8 May; $2=8$ to 15 May; $3=15$ to 22 May; $4=$ 22 to 29 May; $5=29$ May to 5 June; $6=5$ to 12 June; $7=12$ to 19 June; $8=19$ to 26 June; $9=26$ June to $3 \mathrm{July} ; 10=3$ to $10 \mathrm{July} ; 11=10$ to $17 \mathrm{July} ; 12=17$ to $24 \mathrm{July} ; 13=24$ to $31 \mathrm{July} ; 14=31$ July to 7 Aug.; $15=7$ to 14 Aug.; $16=14$ to 21 Aug.; $17=21=28$ Aug.; $18=28$ Aug. to 4 Sept.

leafhopper subfamilies were collected from the traps during the growing season (Table 3). Of the species, Agallia quadripunctata, Empoasca fabae and $G$. versuta were the most abundant. Of these three species, Empoasca fabae was the most evenly distributed among the elm selections, ranging from $1.5 \%$ to $4.3 \%$, than Agallia quadripunctata (range $0.02 \%$ to $9.6 \%$ ) or G. versuta (range $0.7 \%$ to $8.8 \%$ ) (Table 3 ). Agallia quadripunctata was the most dominant species collected from U. bergmanniana 68997 and U. szechuanica 68991, while Empoasca fabae was the most dominant species among the other elm selections. Eleven of the leafhopper species were collected from each of the seven elm selections. Less than 10 individuals were collected for 15 of the species. Leafhoppers of Coelidia olitoria, Scaphoideus intricatus and of Scaphoideus luteolus were collected from trees of the three cultivars only, while G. coccinea was collected only from the four USNA seedling selections. Leafhoppers of Scaphytopius frontalis and of Ponana scarlatina were collected only from 'Prospector' and 'Patriot', while Ery. ziczac was collected only from 'Prospector'.
Most of the leafhopper species were evenly distributed among the elm selections, except for Ery. comes (range $0.04 \%$ to $3.34 \%$ ), and Ribautiana unca (range $0 \%$ to $2.3 \%$ ). Most leafhopper species were rare based on their low abundance (Table 3).

\section{Discussion}

Several of the 39 species of leafhoppers collected and identified in this study are known to attack a wide variety of woody ornamental plants, explaining in part their occurrence among the trees (Gibson, 1973; Hamilton, 1985; Oman, 1949). The yellow sticky cards were very useful in detecting relative adult leafhopper population trends among the different elm selections, and were very reliable at Although sticky cards have been used successfully as a tool for monitoring leafhopper activity and for timing pesticide applications in settings such as orchards and field crops, this study showed that sticky cards can be used along nursery liners to monitor leafhopper activity, catching leafhoppers at low population levels. and for surveying species composition.

Scaphoideus luteolus is the only confirmed vector of elm yellows in North America (Baker, 1949). In this study, S. luteolus was found only among the elm cultivars. Sinclair (1981) stated that this insect prefers to feed on non-European and non-Asian elm species, explaining, in part, its occurrence among the cultivars. The Cicadellinae leafhopper species found among the elms in this study are vectors of Xylella fastidiosa, the causal agent of bacterial leaf scorch (Bentz and Sherald, 2001). These species differed in their abundance and distribution among the elm selections. Graphocephala versuta, the most abundant of the Cicadellinae, was collected from traps on trees of the seven elm selections. In contrast, the few individuals of $G$. coccinea were collected only from traps on the USNA seedling selections.

It is difficult to predict the factors that influenced the differences in leafhopper species richness or diversity between elm cultivars and USNA seedling selections, and more research is needed to elucidate any regulating mechanism. Intuitively, these elms may have plant traits that are qualitatively similar, but probably quantitatively varying. Leafhoppers were probably influenced by differences in leaf emergence and spring flowering (Bentz and Townsend, 1997), host suitability (Bentz and Townsend, 2001), host plant architecture or vertical stratification (Denno and Roderick, 1991), or by predation or predator-mediated coexistence (Paine, 1966). The observed fluctuations in the species and number of trapped leafhoppers during the season could have resulted, in part, from movement, dispersal, immigration or emigration (Flanders and Radcliffe, 1989), voltinism (Oman, 1949), development and reproduction (Hunter and Yeargan, 1989), predation (Sobrevilla, 1999), or weather (Lindblad and Arenoe, 2002). The ramets and seedling trees used in the study were within 6 to $8 \mathrm{~m}$ in height. Yet, because elms have nonsynchronized-determinant growth on each shoot, which creates architectural complex canopies, this would directly influence the structure of leafhopper assemblages, and not tree height (see Bentz and Townsend, 1997). More research is needed to elucidate the effect of vertical stratification of sticky trap catches of leafhopper adults and the relative contributions of deterministic and stochastic processes in defining the spatial and temporal variation in patterns of leafhopper diversity.

More research is needed to explain the lower richness, abundance and diversity associated with seedlings of $U$. bergmanniana and $U$. szechuanica. These differences could be due to constraints on host plant adaptations (Cronin et al., 2001), or traits associated with host plant resistance (Panda and Khush, 1995). These USNA seedling selections could potentially be resistant to elm yellows due to vector nonpreference (Sinclair, 1981), which needs to be tested. The elm selections studied could potentially succumb to bacterial leaf scorch if found to be suitable hosts to the Cicadellinae vector species. This needs to be tested. The utilization of different seedlots deserves to be studied as a strategy for managing insect pests of elms, as it appears that these differ in their mechanisms 


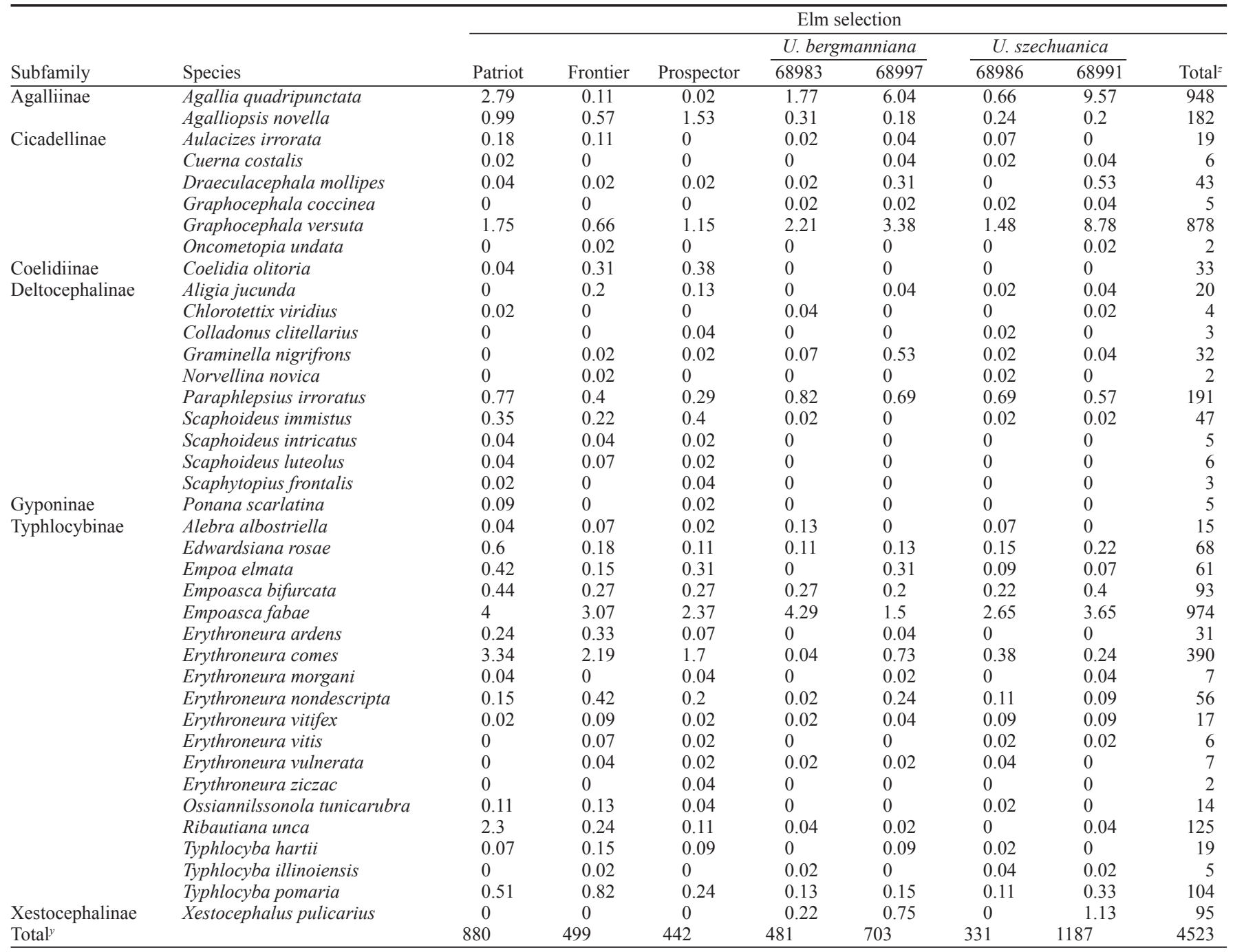

${ }^{z}$ Total number of individuals per species collected during the season.

${ }^{y}$ Total number of individuals collected per elm selection during the season.

of resistance against leafhoppers. This study showed that differences in leafhopper species richness and abundance can be assessed and used as an indicator of potential pest problems in plant resistance programs.

\section{Literature Cited}

Baker, W.L. 1949. Studies on the transmission of the virus causing phloem necrosis of american elm with notes on the biology of its insect vector. J. Econ. Entomol. 42:729-732.

Beirne, B.P. 1956. Leafhoppers (Homoptera: Cicadellidae) of Canada and Alaska. Can. Entomol. 88 (Suppl. 2):1-180.

Bentz, J. and A.M. Townsend. 1997. Variation in adult populations of the potato leafhopper (Homoptera: Cicadellidae) and feeding injury among clones of red maple. Environ. Entomol. 26:1091-1095.

Bentz, J. and A.M. Townsend. 2001. Leafelement content and utilization of maple and elm as hosts by the potato leafhopper (Homoptera: Cicadellidae). Environ. Entomol. 30:533-539.

Bentz, J. and J. Sherald. 2001. Transmission of the xylemlimited bacterium Xylella fastidiosa to shade trees by insect vectors, p. 203-208. In: C.L. Ash (ed.). Shade tree wilt diseases. Proc. APS Wilt Diseases of Shade Trees, National Conference, Minn.

Cronin, J.T., W.G. Abrahamson, and T.P. Craig. 2001 Temporal variation in herbivore host-plant preference and performance: constraints on host-plant adaptation. Oikos 93:312-320.

Denno, R.F. and G.K. Roderick. 1991. Influence of patch size, vegetation texture, and host plant architecture on the diversity, abundance, and life history styles of sap-feeding herbivores, p. 169-196. In: S.S. Bell, E.D. McCoy, and H.R. Mushinsky (eds.). Habitat structure: the physical arrangement of objects in space. Chapman and Hall, London.

Flanders, K.L. and E.B. Radcliffe. 1989. Origins of potato leafhoppers (Homoptera: Cicadellidae) invading potato and snap bean in Minnesota. Environ. Entomol. 18:1015-1024

Gleason, M.L. 2001. Phytoplasma-incited diseases of trees: Ash yellows and elm yellows, p. 223-227. In: C.L. Ash (ed.). Shade tree wilt diseases. Proc. APS Wilt Diseases of Shade Trees: National Conference, Minn.

Gibson, L.P. 1973. An annotated list of the Cicadellidae and Fulgoridae of elm. U.S. For. Serv. Res. Pap. NE-278.

Hammer, Ø., D.A.T. Harper, and P.D. Ryan. 2004 PAST-Palaeontological statistics. ver. 1.20.

Hamilton, K.G.A. 1985. Leafhoppers of ornamental and fruit trees in Canada. Agr. Can. Publ. 1779/ E.:1-71.

Hunter, C.E. and K.V. Yeargan. 1989. Development, reproduction, and competitive interactions between two sympatric leafhopper species (Homoptera: Cicadellidae) on redbud trees. Environ. Entomol. 18:127-132.

Krebs, C.J.2002.Ecological methodology. 2nded. Exeter
Software, N.Y.

Lindblad, M. and P. Arenoe. 2002. Temporal and spatial population dynamics of Psammotettix alienus, a vector of wheat dwarf virus. Intl. J. Pest Mgt. 48:233-238.

Littell, R.C., G.A. Milliken, W.W. Stroup, and R.D. Wolfinger. 1996. SAS system for mixed models. SAS Institute, Cary, N.C.

Magurran, A.E. 2003. Measuring biological diversity. Blackwell, Oxford.

Oman, P.W. 1949. The Neartic leafhoppers (Homoptera: Cicadellidae): A generic classification and check list. Wash. Entomol. Soc. Mem. 3:1-253.

Paine, R.T. 1966. Food web complexity and species diversity. Amer. Nat. 100:65-75.

Panda, N. and G.S. Khush. 1995. Host plant resistance to insects. CAB Intl.-Intl. Rice Res. Inst., Wallingford, Oxon, U.K.

Purcell, A.H. and J.S. Elkinton. 1980. A comparison of sampling methods for leafhopper vectors of X-disease in California cherry orchards. J. Econ. Entomol. 73:854-860.

SAS Institute. 1999. SAS user's guide: statistics. SAS Institute, Cary, N.C.

Sinclair,W.A. 1981.Elmyellows, p. 25-31. In: R.J Stipes and R.J. Campana (eds.). Compendium of elm diseases. Amer. Phytopathol. Soc., St. Paul, Minn.

Sobrevilla, L.G. 1999 Population dynamics of the variegated leafhopper, Erythroneura variabilis Beamer and its egg parasitoids in northwestern Mexico. S.W. Entomol. 24:243-248. 